\title{
Planning the peninsula-wide recovery of the Iberian lynx: identification of favourable habitat areas
}

https://doi.org/10.1515/mammalia-2019-0052

Received May 8, 2019; accepted November 27, 2019

\section{Introduction}

The history of human coexistence with large carnivores is dominated by direct persecution of the latter by the former, which has led to generalised declines in carnivore populations. However, over the past few decades, some stabilisation or even increase in the abundance of some species of carnivores has occurred. The main causes behind this change in trend are (1) protective legislation, (2) increased support from public opinion, (3) a variety of practices that favour coexistence between large carnivores and humans (Chapron et al. 2014) and (4) the depopulation of rural areas and consequent growth of cities. Nevertheless, in certain areas from where large carnivores have completely disappeared, proactive initiatives and strategies are still considered as a necessary means towards recolonisation, as is the case with the reintroduction projects targeting the Eurasian lynx (Lynx lynx (Linnaeus, 1758); Breitenmoser et al. 1993), black bear (Ursus americanus (Pallas, 1780); Smith and Clark 1994), grey wolf (Canis lupus (Linnaeus, 1758); Ripple and Beschta 2012) and Iberian lynx (Lynx pardinus (Temminck, 1827); Simón 2012).

Endemic to the Iberian Peninsula (Boscaini et al. 2015), the Iberian lynx is a strict trophic specialist that is dependent on the European rabbit (Oryctolagus cuniculus (Linnaeus, 1758); Delibes et al. 2000). It reached its maximum distribution in the Late Pleistocene, when it occurred throughout the Iberian Peninsula and south of France (Kurtén and Granqvist 1987, Yravedra 2005). During the Late Glacial, the Iberian lynx probably cooccurred with the Eurasian lynx in the northern part of its former range (Sommer and Benecke 2006). Although still present in most regions of the Iberian Peninsula at the end of the 19th century (Graells 1897), during the 20th century it began to disappear from much of its original distribution area, and by the 1980s it was estimated that only 1000-1200 Iberian lynx remained, distributed in nine isolated populations in the south-western quadrant of the Peninsula (Rodríguez and Delibes 1992) (Figure 1). The species reached its all-time minimum in the first years of the 21st century, when 100 individuals in just two 

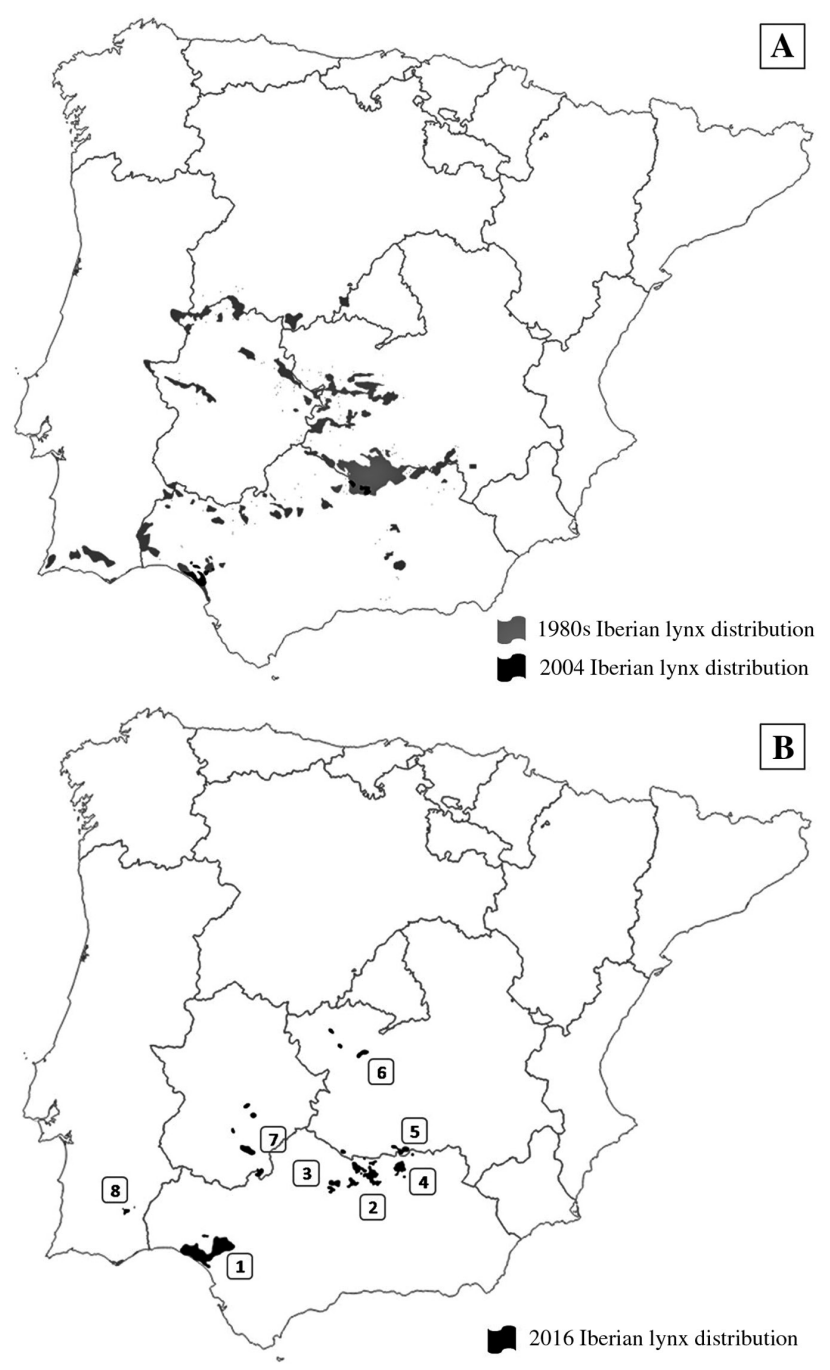

Figure 1: Iberian lynx distribution in the Iberian Peninsula. (Map A) Recent historical distribution (Rodríguez and Delibes 1992, Guzmán et al. 2004). (Map B) Current distribution (Junta de Andalucía 2019). Populations: (1) Doñana, (2) Andujar-Cardeña, (3) Guadalmellato, (4) Guarrizas, (5) Eastern Sierra Morena, (6) Montes de Toledo, (7) Matachel, (8) Vale do Guadiana.

isolated populations - Andújar-Cardeña and Doñana were known to exist (Guzmán et al. 2004) in a total occupied surface area of $500 \mathrm{~km}^{2}$, equivalent to $0.064 \%$ of the surface area of Spain (Figure 1). The main causes of this dramatic downturn were (1) unnatural mortality (mainly persecution by humans), (2) habitat loss and fragmentation and (3) a decline in rabbit populations due to disease [myxomatosis and rabbit haemorrhagic disease (RHD); Rodríguez and Delibes 1992, Guzmán et al. 2004]. This serious situation led to the Iberian lynx being classified by the International Union for Conservation of Nature (IUCN) as Critically Endangered in 2002 (IUCN 2002). In order to invert the species' demographic trend, proactive management was required to counteract the harmful effects of the lack of prey and the random fluctuations that can severely affect extremely small populations (Ferreras et al. 2010). Since 2002, Iberian lynx conservation projects have included actions focused on increasing the carrying capacity of the habitats they occupy (including improving populations of wild rabbit), decreasing known causes of mortality and creating new populations through reintroductions (Simón 2012). In 2009, releases began in two areas of Sierra Morena, a mountainous area from where the Iberian lynx had become extinct in the late 20th century (Guadalmellato and Guarrizas). These populations have established themselves, and continuous exchanges showing metapopulation dynamics now occur with the population in Andújar-Cardeña (Junta de Andalucía 2019). In 2014, reintroduction projects began in four new areas outside the Andalusian Autonomous Region, including eastern Sierra Morena (Castilla-La Mancha), Montes de Toledo (Castilla-La Mancha), Valle de Matachel (Extremadura) and Vale do Guadiana (Southern Portugal) (Figure 1). These populations are currently in the process of establishment and so it is too early to make an assessment of their success or failure. By 2018, the minimum number of Iberian Lynx detected in the wild was estimated at 686 (Junta de Andalucía 2019), nearly 7 times more than just over a decade before.

The positive evolution of the species over the past decade has led the IUCN to lower its threat category from Critically Endangered to Endangered (Rodríguez and Calzada 2015). Nevertheless, despite these results, the future of the species is still uncertain. The low number of individuals and populations, the loss of genetic variability, the risk of contracting diseases, unnatural mortality and the viral diseases affecting rabbits are all factors that continue to threaten this lynx (Casas-Marce et al. 2013, López et al. 2014, Monterroso et al. 2016). Given that despite the population growth experienced in the last decade, no new population was created by natural recolonisation, its long-term conservation must inevitably involve continuing to create new populations through reintroductions (Breitenmoser et al. 2006, Ferreras et al. 2010). The correct selection of reintroduction areas is a crucial step in the process of recovering extinct populations of endangered species (Breitenmoser et al. 2001, Schadt et al. 2002).

Finding suitable and available habitat for threatened species is a crucial part of the design and feasibility of reintroduction projects (IUCN/SSC 2013). Species distribution models (SDMs) are the main tools currently being used to derive spatially explicit predictions of environmental suitability for species (Guisan and Thuiller 2005, 
Elith and Leathwick 2009, Franklin 2010, Peterson et al. 2011). Species reintroduction programmes in particular can benefit from this type of predictive modelling (Cramer and Portier 2001) as they represent an important first step for detecting key areas for carrying out reintroductions (Tatcher et al. 2006). Some studies have satisfactorily modelled spatial factors that determine the distribution of the Iberian lynx at a local scale (Fernández et al. 2006). Other peninsula-wide habitat suitability models have been drawn up that place greater emphasis on bioclimatic as opposed to vegetation coverage variables (Real et al. 2009, Fordham et al. 2013), which means that no information can be obtained on important aspects such as habitat quality or fragmentation. Given the current situation of the Iberian lynx, a large-scale assessment of habitat suitability was a necessary prerequisite for the evaluation of current lynx reintroduction projects and management actions (Schadt et al. 2002). The objective of this study was (1) to develop a habitat suitability model for the Iberian lynx in the Iberian Peninsula, and (2) to identify habitat patches that could harbour stable populations of the species in the long term as a basis for the establishment of priority areas for future reintroduction and conservation actions.

\section{Materials and methods}

\section{Species presence data}

The presence data used data provided by the environment council of the government of Andalucia, and comes from projects funded by the LIFE programme. The LIFE programme is a European Union instrument to finance environmental conservation projects. Lynx presence data provided were obtained using radio-tracking and camera-trapping data (Simón et al. 2012). Only presence data for 2010-2013 from the historic Andujar-Cardeña and Doñana lynx populations were used. The study area was divided into $500 \times 500 \mathrm{~m}$ grid squares, and squares in which lynx were present in 3 consecutive years were considered as established areas of presence; squares with occasional locations ( $<3$ consecutive years presence) were discarded.

Presence data from new populations created through reintroductions were not included. The selection of these areas was made using a model similar to the one presented here. The non-inclusion of these data avoids circular reasoning in our model, such as selecting appropriate areas based on the presence of individuals released in areas predefined as suitable for reintroduction.

\section{Environmental data}

Land cover variables obtained from the CORINE LAND COVER 2006 map were used. For each $500 \times 500 \mathrm{~m}$ grid square, a percentage of occupied surface area was assigned to each of the variables considered. Twentynine categories were used, which were grouped into 11 variables with biological relevance for the Iberian lynx (CORINE land cover class codes included) as follows:

(a) Artificial land cover (all classes 1.x)

(b) Agricultural areas (all classes 2.1.x, 2.2.x and 2.3.1, 2.4.1, 2.4.2)

(c) Agroforestry systems without natural vegetation (2.4.4)

(d) Agroforestry systems with natural vegetation (2.4.3)

(e) Deciduous woodland (3.1.1)

(f) Conifer woodland (3.1.2)

(g) Mixed woodland (3.1.3)

(h) Natural pastures (3.2.1)

(i) Mesophilic heath and scrubland (3.2.2)

(j) Sclerophyllous scrubland (3.2.3)

(k) Transitional wooded scrubland (3.2.4).

\section{Species distribution model}

We modelled habitat suitability for the Iberian lynx using MaxEnt, a general-purpose method for characterising species habitat associations from presence-background data that has proven to be more robust and precise than other methods (Elith et al. 2006). MaxEnt is a maximumentropy-based machine-learning program that estimates the probable distribution of a species based on environmental constraints (Phillips et al. 2006). It seeks a marginal suitability function for each variable that matches the empirical data; it is mainly uninformative (close to the uniform distribution) for most of the environmental range and has a mean that is equal to that of the empirical data (Warren and Seifert 2011). The latter property can have the undesired result of over-fitting the data used to train the model and so MaxEnt has a regularisation parameter that can be used to tune the model to avoid such over-fitting (Tellería et al. 2012). The algorithm performs a certain number of iterations until it reaches a convergence limit and then transfers the equation to the geographical space, thereby generating a raster layer whose values represent the environmental suitability of the species on a scale from 0 (unsuitable) to 1 (perfectly suitable). The program uses two types of data input: localities where the species has been recorded (presence-only data) and digital layers of the environmental conditions of a given area. To generate the suitability map, MaxEnt compares the 
environmental conditions for the presence data in relation to a random set of data, which represents the set of conditions present in the territory.

In this study, the following settings of MaxEnt version 3.4.1k (http://www.cs.princeton.edu/schapire/ Maxent) were used: regularisation multiplier $b=1$; number of background points $=10,000$; convergence threshold $=0.00001$. Only linear, quadratic and product features were used to promote smoothed response curves and model interpretablility (Merow et al. 2013). Background points must be selected from areas representing the full environmental range of the species (Phillips et al. 2009, Elith et al. 2011). Given that the lynx was once distributed throughout the entire Iberian Peninsula, background points were randomly selected from the whole of the Iberian Peninsula. We ran 10 replicates, in each of which we trained the model with $70 \%$ of the presences and performed the MaxEnt intrinsic test validation with the remaining $30 \%$, using the sub-sample option to remove the random test percentage without replacement for evaluation. The final model was the average of the replicates. The discrimination capacity of the model was evaluated by analysing the ROC curves (receiving operating characteristics) and calculating the mean AUC (area under the curve). The cloglog output was selected to obtain presence probability from distribution models (Phillips et al. 2017) which were subsequently converted to binary presence-absence values on the basis of the established threshold value. For this study, we decided to use the Maximum test sensitivity plus specificity threshold which maximises the probability of species detection in the test data. For our purposes, this threshold allowed us to evaluate the species' distribution by minimising omission errors in our final binary maps (Ortega-Andrade et al. 2013). This threshold is automatically computed by MaxEnt from the subsample of occurrences used for model evaluation for each run.

Altitude is a threshold imposed by the availability of food. The upper altitudinal limit for the European rabbit was found to be $1300 \mathrm{~m}$ (Blanco and Villafuerte 1993). Once the model had been designed, all areas above $1300 \mathrm{~m}$ were considered as unsuitables and were eliminated from the model.

The National Strategy for the conservation of the Iberian lynx (GTLI 2008) states that the minimum surface area for a viable long-term lynx population (50 breeding animals) must contain at least 10,000 continuous hectares of suitable habitat. Thus, all smaller patches of suitable habitat were eliminated from the model.

The EU legislated Natura 2000 network of protected areas were designed to conserve the habitat of the species included in its annexes, such as the Iberian lynx. The suitability map obtained was cross-referenced with the Natura 2000 network of protected areas in order to establish the amount of suitable habitat protected under EU legislation.

\section{Results}

After the application of the Maximum test sensitivity plus specificity threshold ( 0.365 in average for all runs), a total of $1285500 \times 500-m$ squares with a stable presence of the Iberian lynx were identified. The habitat suitability model predicted an environmentally suitable area of $87,747 \mathrm{~km}^{2}$, which represents $14.08 \%$ of the surface area of the Iberian Peninsula (Figure 2). The calculated average training AUC for the replicate run was $0.863( \pm 0.006)$, which indicates a good model (Hosmer and Lemeshow 2000).

Based on percent contribution, "agricultural areas" was the most important variable followed by "transitional wooded scrubland" (45.9\% and $20.8 \%$, respectively) (Table 1). Based on permutation importance, "transitional wooded scrubland" was the most significant variable (25.4\%) followed by "agricultural areas" (23\%) and "conifer woodland" (16.6\%). Variables "transitional wooded scrubland" and "conifer woodland" positively influenced the lynx habitat suitability for the lynx, while the influence of "agricultural areas" was detrimental.

A total of 148 patches of over 10,000 ha were identified, of which the largest continuous patch of habitat is located in the south-western quadrant $\left(21,333.75 \mathrm{~km}^{2}\right)$ (Figure 2).

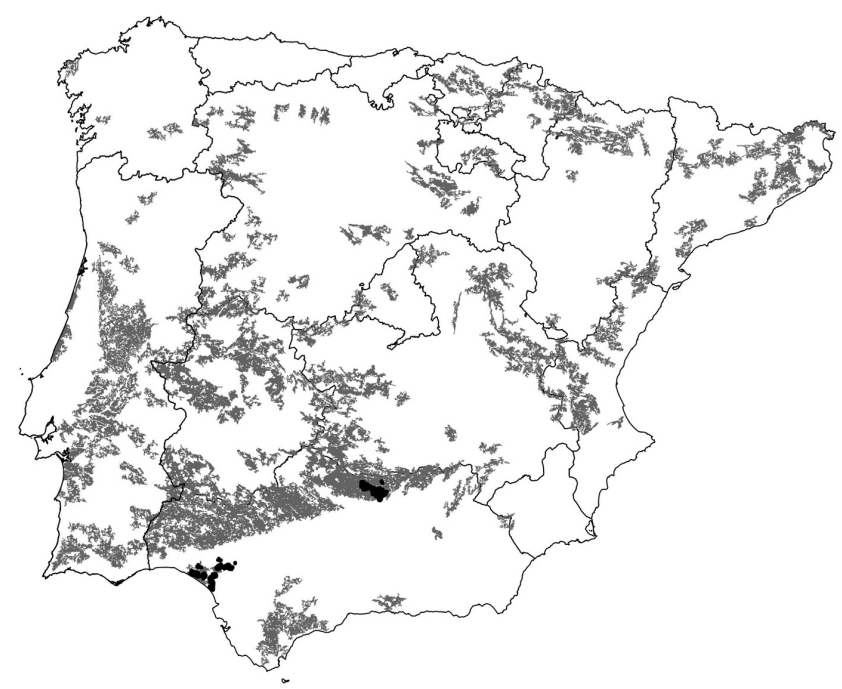

Figure 2: Binary habitat suitability map for the Iberian lynx in the Iberian Peninsula.

Habitat patches over 10,000 ha (grey) and presence data (black) are represented. 
Table 1: Estimates of relative contributions of the environmental variables.

\begin{tabular}{lrr}
\hline Variable & $\begin{array}{r}\text { Percent } \\
\text { contribution }\end{array}$ & $\begin{array}{r}\text { Permutation } \\
\text { importance }\end{array}$ \\
\hline Agricultural areas & 45.9 & 23 \\
Transitional wooded scrubland & 20.8 & 25.4 \\
Conifer woodland & 8.6 & 16.6 \\
Agroforestry systems with natural vegetation & 6.2 & 7.2 \\
Natural pastures & 3.9 & 2.4 \\
Mesophilic heath and scrubland & 3.7 & 2.2 \\
Mixed woodland & 3.4 & 6.5 \\
Agroforestry systems without natural vegetation & 2.6 & 6.4 \\
Artificial land cover & 2.2 & 1.2 \\
Deciduous woodland & 1.8 & 5.9 \\
Sclerophyllous scrubland & 1 & 3 \\
\hline
\end{tabular}

Percent contribution indicates the change in regularised gain by adding the corresponding variable. Permutation importance represents, for each environmental variable in turn, the resulting drop in training AUC when the values of that variable on training presence and background data are randomly permuted, normalised to show percentages. Values are averages over replicate run.

Forty-five percent $(n=67)$ of the patches identified were smaller than 20,000 ha. Portugal and all the Spanish autonomous regions excepting Principado de Asturias and Cantabria have at least one patch of suitable habitat over 10,000 ha (Table 2). A total of $38,646 \mathrm{~km}^{2}$ of suitable habitat lie within the Natura 2000 network of protected areas.

\section{Discussion}

We developed a statistical habitat model for predicting suitable areas for the Iberian lynx in the Iberian Peninsula.

Table 2: Total and protected surface of suitable habitat in Portugal and the Spanish autonomous regions.

\begin{tabular}{lrr}
\hline & $\begin{array}{r}\text { Total suitable } \\
\left.\text { habitat } \mathbf{( k m}^{2}\right)\end{array}$ & $\begin{array}{r}\text { Protected suitable } \\
\text { habitat } \mathbf{~ k m}^{2}(\%)\end{array}$ \\
\hline Andalucía & 19,440 & $11,475(59)$ \\
Portugal & 16,852 & $4291(25)$ \\
Extremadura & 12,710 & $4288(34)$ \\
Castilla-La Mancha & 11,408 & $5866(51)$ \\
Castilla y León & 8857 & $2921(33)$ \\
Cataluña & 5517 & $3010(55)$ \\
Aragón & 3404 & $1563(46)$ \\
C. Valenciana & 4168 & $3057(73)$ \\
Navarra & 1934 & $847(44)$ \\
País Vasco & 1536 & $510(33)$ \\
La Rioja & 597 & $169(28)$ \\
Galicia & 645 & $44(7)$ \\
Madrid & 586 & $536(91)$ \\
Murcia & 87 & $61(70)$ \\
Cantabria & 0 & 0 \\
Asturias & 0 & 0 \\
\hline
\end{tabular}

The final model identified $14.08 \%$ of the surface area of the Peninsula as suitable for the lynx. In all, $45 \%$ of the total suitable habitat identified is located in a large continuous area in the south-western quadrant coinciding with the historical range of the species since the mid20th century. However, there are also relevant patches of habitat outside its recent historical range, mainly in the north-eastern quadrant (above all, a broad strip in the Pyrenean foothills and a continuous patch shared by eastern Castilla-La Mancha, Comunidad Valenciana and southern Aragón). In the rest of the Peninsula, there are numerous patches with different levels of isolation.

About $55 \%$ of the potential area suitable for the lynx lies outside the protected areas included in the Natura 2000 network. Indeed, 40\% of the species' current range has no form of protection. Therefore, unprotected areas play and will continue to play an important role in the expansion and connection of existing and future populations. The main source of financing for lynx recovery projects comes from LIFE funds. These funds require their application in the Natura 2000 network. This implies that half of the habitat suitable for the lynx, as well as their area of distribution, would be outside the scope of these funds. Unprotected areas identified as highly likely to be used by the Iberian lynx should be considered for future protection. This map of suitable areas should be used as a guide for the creation of new protected areas as a prelude to future reintroductions or, preferably, to natural colonisation.

As observed by other similar studies (Schadt et al. 2002, Osborne and Seddon 2012), a potential problem with this model is that it was built using data from an expanding population. During its recent spread, the 
Iberian lynx has occupied habitats traditionally identified as non-suitable for the species, or apparently suboptimal habitats such as humanized areas, tree crops and agricultural land, where the species has even managed to breed (Garrote et al. 2013, 2016, Gastón et al. 2016). This suggests that the Iberian lynx possesses greater ecological plasticity than previously thought (Garrote et al. 2016), as reflected in the reduction in human-induced mortality rates in more human-altered habitats (López et al. 2014, Gastón et al. 2016), as observed in other carnivores (Lesmerises et al. 2012). Direct human-related mortality outside traditional scrub habitats may have been misinterpreted in the past as due to a lack of habitat resources in certain agricultural areas (Gastón et al. 2016). The presence of the species in these habitats is a recent advance and only involves a small area of the current range of the species. However, as knowledge of the species' distribution and habitat use grows, this information must be incorporated into the development of updated models. In the same way, other land cover classes are located far from the current lynx populations, so there is no available information on its use by the species (e.g. ix-Mesophilic heath and scrubland). With current presence data, MaxEnt attributes a low percent contribution to this land cover class. Nevertheless, it could be potentially suitable if enough density of preys was available.

Given that our models required explanatory variables mapped uniformly throughout the entire Iberian Peninsula, we were not able to directly consider some known drivers of Iberian lynx habitat selection such as prey density, disease, non-natural mortality risk, fine-scale forest canopy cover and vegetation height (Gastón et al. 2016). Rabbit density is one of the most important factors for identifying potential areas for lynx reintroduction. Despite the lack of quality information on rabbit populations in the Peninsula, some relevant conclusions can be drawn from the map generated and from previous information on rabbit distribution. In the late 1980s, Iberian rabbit populations were seriously affected by RHD (Villafuerte et al. 1994); today some have disappeared, while others remain that are small and isolated (Virgós et al. 2003). In fact, during the most recent national census of the Iberian lynx (Guzmán et al. 2004), it was found that in $85 \%$ of the sampled area, corresponding to the recent historical distribution of the species (1980s) (Rodríguez and Delibes 1992), rabbit populations had disappeared or existed in very low densities that were insufficient to maintain an Iberian lynx population. The areas with the best rabbit populations were isolated, thereby making the natural colonisation by the Iberian lynx of these areas from their areas of stable presence unlikely. Since then, the situation does not seem to have improved. In recent years, the identification of viable areas for reintroductions in Castilla-La Mancha, Extremadura and Andalusia, as well as sampling aimed at detecting potential areas for interconnecting populations, have located nuclei with rabbits only in the areas previously indicated by Guzmán et al. (2004). In 2011, a new variant of RHD was detected in the Iberian Peninsula (Calvete et al. 2013) and its rapid spread has been associated with a notable decline in rabbit population in some regions of Spain (Delibes-Mateos et al. 2014). Likewise, in the context of the Iberian lynx conservation programme, the impact of this new variant of RHD has caused declines in rabbit populations in all studied areas (López-Parra 2016). This information suggests that the current state of rabbit populations in the 1980s range of the Iberian lynx may in fact be worse than that reported by Guzmán et al. (2004). This implies that the potentially useful area for the lynx within this habitat patch is very small and fragmented, thereby making it impossible - given the absence of rabbits over much of this former range - to fulfil the objective included in the national strategy aimed at restoring the species to its 1980 area of distribution. Therefore, to achieve the recovery of the species to population levels that will guarantee its long-term survival, the potential habitat areas of the entire Peninsula should be taken into account. Similar recommendations were suggested by Real et al. (2009) and Fordham et al. (2013) modelling environmental favourability for the lynx from different biogeographical approaches. This would be in line with the IUCN/SSC Guidelines for Reintroductions, as originally the species was found throughout the whole Peninsula (Graells 1897). This issue should be included in the Iberian Lynx National Strategy and be clearly specified.

Like other carnivores (Simberloff 1998, Carroll et al. 2001), the lynx is an important conservation flagship species, especially in areas where it is being reintroduced (Schadt et al. 2002). The future of the Iberian lynx depends on our ability to correctly manage reintroduction schemes and on the prior detection of potential areas (Schadt et al. 2002). The habitat suitability model presented here should be considered as a tool that can guide a peninsularwide strategy of creating new populations of Iberian lynx through reintroductions, and for monitoring future work on selecting reintroduction areas in the species' original range. The model must be re-evaluated as fresh information on the presence of the species in new areas (areas of reintroduction or expansion) becomes available as a way of improving its accuracy and reflecting the species' ecological flexibility. The existence of possible interconnection areas and corridors should be studied in later phases 
with a view to favouring the species' future self-sustaining dynamics in metapopulations in the Iberian Peninsula.

Acknowledgements: The study was supported by the LIFE Project 10NAT/ES/570 "Recovery of the historical distribution of the Iberian lynx (Lynx pardinus) in Spain and Portugal". We thank all the staff of the LIFE projects involved in collecting Iberian lynx distribution data, Sonia Illanas, Antón Álvarez and Guillermo Fandos and the anonymous reviewers for their constructive comments.

\section{References}

Blanco, J.C. and R. Villafuerte. 1993. Factores ecológicos que influyen sobre las poblaciones de conejos. Incidencia de la enfermedad hemorrágica. Technical report. Empresa de Transformación Agraria, S.A. Madrid. Spain.

Boscaini, A., J. Madurell-Malapeira, M. Llenas and B. MartínezNavarro. 2015. The origin of the critically endangered Iberian lynx: speciation, diet and adaptive changes. Quat. Sci. Rev. 123: 247-253.

Breitenmoser, U., P. Kavczensky, M. Dötterer, C. BreitenmoserWürsten, S. Capt, F. Bernhart and M. Liberek. 1993. Spatial organization and recruitment of lynx (Lynx lynx) in a reintroduced population in the Swiss Jura Mountains. J. Zool. 231: 449-464.

Breitenmoser, U., C. Breitenmoser-Würsten, L.N.N. Carbyne and S.M.M. Funk. 2001. Assessment of carnivore reintroductions. In: (J.L. Gittleman, S.M. Funk, D.W. Macdonald and R.K. Wayne, eds.) Carnivore conservation. Cambridge University Press, Cambridge, England. pp. 241-281.

Breitenmoser, U., C. Breitenmoser Würsten, J.G. Santiago and F. Zimmermann. 2006. The IUCN/SSC red list assessment, reintroduction guidelines and the Iberian Lynx. Applying the red list criteria to define a recovery strategy for the Iberian lynx. In: (Junta de Andalucía, ed.) II International Seminar on Conservation of Iberian Lynx. Junta de Andalucía, Jaén, España. pp. 45-50.

Calvete, C., J.H. Calvo and P. Sarto. 2013. Detection of a new variant of rabbit hemorrhagic disease virus in wild rabbits in Spain. World Rabbit Sci. 21: 52-53.

Carroll, C., R.F. Noss and P.C. Paquet. 2001. Carnivores as focal species for conservation planning in the rocky mountain region. Ecol. Appl. 11: 961-980.

Casas-Marce, M., L. Soriano, J.V. López-Bao and J.A. Godoy. 2013. Genetics at the verge of extinction: insights from the Iberian lynx. Mol. Ecol. 22: 5503-5515.

Chapron, G., P. Kaczensky, J.D.C. Linnell, M. Von Arx, D. Huber, H. Andrén, J.V. López-Bao, M. Adamec, F. Álvares, O. Anders, L. Balečiauskas, V. Balys, P. Bedo, F. Bego, J.C. Blanco, U. Breitenmoser, H. Broseth, L. Bufka, R. Bunikyte, P. Ciucci, A. Dutsov, T. Engleder, C. Fuxjäger, C. Groff, K. Holmala, B. Hoxha, Y. Iliopoulos, O. Ionescu, J. Jeremić, K. Jerina, G. Kluth, F. Knauer, I. Kojola, I. Kos, M. Krofel, J. Kubala, S. Kunovac, J. Kusak, M. Kutal, O. Liberg, A. Majić, P. Männil, R. Manz, E. Marboutin, F. Marucco, D. Melovski, K. Mersini, Y. Mertzanis, R.W. Mystajek, S. Nowak,
J. Odden, J. Ozolins, G. Palomero, M. Paunović, J. Persson, H. Potoečnik, P.Y. Quenette, G. Rauer, I. Reinhardt, R. Rigg, A. Ryser, V. Salvatori, T. Skrbinšek, A. Stojanov, J.E. Swenson, L. Szemethy, A. Trajçe, E. Tsingarska-Sedefcheva, M. Váňa, R. Veeroja, P. Wabakken, M. Wölfl, S. Wölfl, F. Zimmermann, D. Zlatanova and L. Boitani. 2014. Recovery of large carnivores in Europe's modern human-dominated landscapes. Science 346: 1517-1519.

Cramer, P.C. and K.M. Portier. 2001. Modeling Florida panther movements in response to human attributes of the landscape and ecological settings. Ecol. Modell. 140: 51-80.

Delibes, M., A. Rodríguez and P. Ferreras. 2000. Action Plan for the conservation of the Iberian Lynx (Lynx pardinus) in Europe. Nat. Environ. 111: 1-40.

Delibes-Mateos, M., C. Ferreira, F. Carro, M.A. Escudero and C. Gortázar. 2014. Ecosystem effects of variant rabbit hemorrhagic disease virus, Iberian Peninsula. Emerg. Infect. Dis. 20: 2166-2168.

Elith, J. and J.R. Leathwick. 2009. Species distribution models: ecological explanation and prediction across space and time. Annu. Rev. Ecol. Evol. Syst. 40: 677-697.

Elith, J., C.H. Graham, R.P. Anderson, M. Dudík, S. Ferrier, A. Guisan, R.J. Hijmans, F. Huettmann, J.R. Leathwick, A. Lehmann, J. Li, L.G. Lohmann, B.A. Loiselle, G. Manion, C. Moritz, M. Nakamura, Y. Nakazawa, J.M. Overton, A.T. Peterson, S.J. Phillips, K. Richardson, R.S. Pereira, R.E. Schapire, J. Soberón, S. Williams, M.S. Wisz and N.E. Zimmermann. 2006. Novel methods improve prediction of species' distributions from occurrence data. Ecography (Cop.). 29: 129-151.

Elith, J., S.J. Phillips, T. Hastie, M. Dudík, Y.E. Chee and C. Yates. 2011. A statistical explanation of MaxEnt for ecologists. Divers. Distrib. 17: 43-57.

Fernández, N., M. Delibes and F. Palomares. 2006. Landscape evaluation in conservation: molecular sampling and habitat modeling for the Iberian lynx. Ecol. Appl. 16: 1037-1049.

Ferreras, P., A. Rodríguez, F. Palomares and M. Delibes. 2010. Iberian lynx: the uncertain future of a critically endangered cat. In: (D. Macdonald and A. Loveridge, eds.) The biology and conservation of wild felids. Oxford University Press, Oxford, UK. pp. 507-520.

Fordham, D.A., H.R. Akçakaya, B.W. Brook, A. Rodríguez, P.C. Alves, E. Civantos, M. Triviño, M.J. Watts and M.B. Araújo. 2013. Adapted conservation measures are required to save the Iberian lynx in a changing climate. Nat. Clim. Chang. 3: 899-903.

Franklin, J. 2010. Mapping species distributions: spatial inference and prediction. Cambridge University Press, Cambridge, UK.

Garrote, G., G. López, J.M. Gil-Sánchez, E. Rojas, M. Ruiz, J.F. Bueno, S. de Lillo, J. Rodriguez-Siles, J.M. Martín, J. Pérez, M. GarcíaTardío, G. Valenzuela and M.A. Simón. 2013. Human-felid conflict as a further handicap to the conservation of the critically endangered Iberian lynx. Eur. J. Wildl. Res. 59: 287-290.

Garrote, G., G. López, J.F. Bueno, M. Ruiz, S. Lillo and M.A. Simón. 2016. Iberian lynx (Lynx pardinus) breeding in olive tree plantations. Mammalia 8: 405-409.

Gastón, A., S. Blázquez-Cabrera, G. Garrote, M.C. Mateo-Sánchez, P. Beier, M.A. Simón and S. Saura. 2016. Response to agriculture by a woodland species depends on cover type and behavioural state: insights from resident and dispersing Iberian lynx. J. Appl. Ecol. 53: 814-824.

Graells, M. 1897. Fauna Mastodológica Ibérica. Real Academia de Ciencias Exactas, Físicas y Naturales. Madrid., Madrid, España. 
Guisan, A. and W. Thuiller. 2005. Predicting species distribution: offering more than simple habitat models. Ecol. Lett. 8: 993-1009.

Guzmán, J.N., F. García, G. Garrote, R. Perez de Ayala and C. Iglesias. 2004. El lince ibérico (Lynx pardinus) en España y Portugal. Censo-diagnóstico de sus poblaciones. Dirección General para la Biodiversidad, Madrid, España.

Hosmer, D.W. and S. Lemeshow. 2000. Applied logistic regression, 2nd. ed, Wiley Series in Probability and Statistics. John Wiley Sons, Inc., New York, NY, USA. https://doi. org/10.2307/2074954.

IUCN. 2002. 2002 IUCN red list of threatened animals. Gland, Cambridge.

IUCN/SSC. 2013. IUCN Guidelines for Reintroductions and Other Conservation Translocations. Version 1.0. IUCN Species Survival Commission, viiii 57 pp, Gland, Switzerland. https:// doi.org/10.1016/j.biocon.2015.07.030.

Junta de Andalucía. 2019. Censo de las poblaciones de lince ibérico. Año 2019. Technical report. Junta de Andalucía.

Kurtén, B. and E. Granqvist. 1987. Fossil pardel lynx (Lynx pardina spelaea Boule) from a cave in southern France. Ann. Zool. Fennici 24: 39-43.

Lesmerises, F., C. Dussault and M. St-Laurent. 2012. Wolf habitat selection is shaped by human activities in a highly managed boreal forest. For. Ecol. Manage. 276: 125-131.

López-Parra, M. 2016. Hábitat y presa en las actuales áreas linceras. In: Junta de Andalucía. V International Seminar on Conservation of Iberian Lynx: Reintroduction Strategies. LIFE+Iberlince. Junta de Andalucía, Seville, Spain.

López, G., M. López-Parra, G. Garrote, L. Fernández, T. Rey-Wamba, R. Arenas-Rojas, M. García-Tardío, G. Ruiz, I. Zorrilla, M. Moral and M.A. Simón. 2014. Evaluating mortality rates and causalities in a critically endangered felid across its whole distribution range. Eur. J. Wildl. Res. 60: 359-366.

Merow, C., M.J. Smith and J.A. Silander. 2013. A practical guide to MaxEnt for modeling species' distributions: what it does, and why inputs and settings matter. Ecography (Cop.). 36: 1058-1069.

Monterroso, P., G. Garrote, A. Serronha, E. Santos, M. DelibesMateos, J. Abrantes, R. Perez de Ayala, F. Silvestre, J. Carvalho, I. Vasco, A.M. Lopes, E. Maio, M.J. Magalhães, L. Scott Mills, P.J. Esteves, M.A. Simón and P.C. Alves. 2016. Disease-mediated bottom-up regulation: an emergent virus affects a keystone prey, and alters the dynamics of trophic webs. Sci. Rep. 6: 36072 .

Ortega-Andrade, H.M., O. Rojas-Soto and C. Paucar. 2013. Novel data on the ecology of Cochranella mache (Anura: Centrolenidae) and the importance of protected areas for this critically endangered glassfrog in the Neotropics. PLoS One 8: e81837.

Osborne, P.E. and P.J. Seddon. 2012. Selecting suitable habitats for reintroductions: variation, change and the role of species distribution modelling. In: (J.G. Ewen, D.P. Armstrong, K.A. Parker and P.J. Seddon, eds.) Reintroduction biology: integrating science and management. John Wiley Sons, Ltd, Chichester, UK. pp. 73-104.

Peterson, A.T., J. Soberón, R.G. Pearson, R.P. Anderson, E. MartínezMeyer, M. Nakamura and M.B. Araújo. 2011. Ecological niches and geographic distributions, Monographs in Population Biology. Princeton University Press, Princeton, NJ, USA.

Phillips, S.J., R.P. Anderson and R.E. Schapire. 2006. Maximum entropy modeling of species geographic distributions. Ecol. Modell. 190: 231-259.
Phillips, S.J., M. Dudík, J. Elith, C.H. Graham, A. Lehmann, J. Leathwick and S. Ferrier. 2009. Sample selection bias and presenceonly distribution models: implications for background and pseudo-absence data. Ecol. Appl. 19: 181-197.

Phillips, S.J., R.P. Anderson, M. Dudík, R.E. Schapire and M.E. Blair. 2017. Opening the black box: an open-source release of MaxEnt. Ecography (Cop.). 40: 887-893.

Real, R., A.M. Barbosa, A. Rodríguez, F.J. García, J.M. Vargas, J.J. Palomo and M. Delibes. 2009. Conservation biogeography of ecologically interacting species: the case of the Iberian lynx and the European rabbit. Divers. Distrib. 15: 390-400.

Ripple, W.J. and R.L. Beschta. 2012. Trophic cascades in Yellowstone: the first $15 y e a r s$ after wolf reintroduction. Biol. Conserv. 145: 205-213.

Rodríguez, A. and J. Calzada. 2015. Lynx pardinus: the IUCN Red List of Threatened Species 2015: e.T12520A50655794.

Rodríguez, A. and M. Delibes. 1992. Current range and status of the Iberian lynx Felis pardina Temminck, 1824 in Spain. Biol. Conserv. 61: 189-196.

Schadt, S., E. Revilla, T. Wiegand, F. Knauer, P. Kaczensky, U. Breitenmoser, L. Bufka, J. Červený, P. Koubek, T. Huber, C. Staniša and L. Trepl. 2002. Assessing the suitability of central European landscapes for the reintroduction of Eurasian lynx. J. Appl. Ecol. 39: 189-203.

Simberloff, D. 1998. Flagships, umbrellas, and keystones: is single-species management passé in the landscape era? Biol. Conserv. 83: 247-257.

Simón, M.A. (ed.) 2012. Ten years conserving the Iberian lynx. Consejería de Agricultura, Pesca y Medio Ambiente, Junta de Andalucía, Seville.

Simón, M.Á., J.M. Gil-Sánchez, G. Ruiz, G. Garrote, E. McCain, L. Fernández, M. López-Parra, E. Rojas, R. Arenas-Rojas, T. del Rey, M. García-Tardío and G. López. 2012. Reverse of the decline of the endangered Iberian Lynx. Conserv. Biol. 26: 731-736.

Smith, K.G. and J.D. Clark. 1994. Black Bears in Arkansas: characteristics of a successful translocation. J. Mammal. 75: 309-320.

Sommer, R.S. and N. Benecke. 2006. Late Pleistocene and Holocene development of the felid fauna (Felidae) of Europe: a review. J. Zool. 269: 7-19.

Tatcher, C.A., F.T. Van Manen and J.D. Clark. 2006. Identifying suitable sites for Florida panther reintroduction. J. Wildl. Manage. 70: 752-763.

Tellería, J.L., T. Santos, P. Refoyo and J. Muñoz. 2012. Use of ring recoveries to predict habitat suitability in small passerines. Divers. Distrib. 18: 1130-1138.

Villafuerte, R., C. Calvete, C. Gortázar and S. Moreno. 1994. First epizootic of rabbit hemorrhagic disease in free living populations of Oryctolagus cuniculus at Doñana National Park, Spain. J. Wildl. Dis. 30: 176-179.

Virgós, E., S. Cabezas-Díaz, A. Malo, J. Lozano and D. López-Huertas. 2003. Factors shaping European rabbit abundance in continuous and fragmented populations of central Spain. A. Theriol. 48: 113-122.

Warren, D.L. and S.N. Seifert. 2011. Ecological niche modeling in MaxEnt: the importance of model complexity and the performance of model selection criteria. Ecol. Appl. 21: 335-342.

Yravedra, J. 2005. Meat use of lynx (Lynx pardina) inside the Iberian Peninsula during the Upper Pleistocene. Antropologia-Arkeologia 57: 303-311. 